\title{
Biased Agonism of G Protein-Coupled Receptors: A Potential Therapeutic Strategy of Cardiovascular Diseases
}

\author{
Yun Hak Kim ${ }^{1}$, Sae Ock Oh ${ }^{1}$ and Chi Dae Kim ${ }^{2 *}$
}

${ }^{1}$ Departments of Anatomy, School of Medicine, Pusan National University, Yangsan, Gyeongnam 50612, Republic of Korea

${ }^{2}$ Departments of Pharmacology, School of Medicine, Pusan National University, Yangsan, Gyeongnam 50612, Republic of Korea

\begin{abstract}
G Protein-Coupled Receptors (GPCRs) are a family of seven transmembrane receptors, and are major targets of current clinical drugs. Many GPCRs have been successfully targeted by specific drugs which are classified as agonists or antagonists. Classically, the GPCR signal pathways are considered to be regulated by heterotrimeric $\mathrm{G}$ proteins. However, many researches have demonstrated that other molecules, $\beta$-arrestins, participate in the regulation of GPCRs associated intracellular signaling pathways. The major role of $\beta$-arrestins is to desensitize responses to $G$ protein signals and to activate cytoplasmic molecules. GPCR ligands can dominantly activate either the $\mathrm{G}$ protein or $\beta$-arrestin pathway, which is the basis of the biased agonism of GPCR signaling. Both signals represent independent actions, for example, one is beneficial and the other is related to side effect. In this review, we summarize the signaling pathways of GPCRs and current biased agonist research on ligands with a focus on cardiovascular disease.
\end{abstract}

Keywords: Biased agonism; G Protein-Coupled Receptor (GPCR); Cardiovascular disease; $\beta$-arrestin; $G$ protein

\section{Introduction: Brief Review of GPCR Signaling}

G Protein-Coupled Receptors (GPCRs) are a family of seven transmembrane proteins, which together are viewed as one of the largest therapeutic targets in clinical medicine [1,2]. In fact, GPCR ligands account for almost $40 \%$ of approved drugs such as $\alpha$ - and $\beta$-blockers, opiates, $\beta$-agonist and angiotensin-converting enzyme inhibitors $[3,4]$. GPCRs recognize various ligands, including hormones, proteins, peptides, lipids and ions [3-5], and thus, their signals and functions make them attractive drug targets $[1,2,6,7]$.

Classically, agonist binding to GPCRs promotes structural changes that stimulate the activation of heterotrimeric $G$ proteins and lead to the activations of various cytosolic signaling molecules [4,8-10]. It has been demonstrated that binding of agonists to GPCRs promote a desensitization process via GPCR phosphorylation by the G ProteinCoupled Receptor Kinases (GRKs) with the involvement of $\beta$-arrestin [11-14]. These structural changes increase the binding affinities of GPCRs for $\beta$-arrestins, which are known to block $G$ protein signaling [11-16]. $\beta$-arrestins is not only a desensitizer of $G$ protein signals, but also a signaling molecule $[9,14,17]$.

There are many diseases related to GPCRs including Cardiovascular Diseases (CVDs), diabetes and neurologic disorder [1,4,18,19]. Among the diseases, CVDs are one of the most common diseases [20,21]. CVDs, such as, atherosclerosis, coronary artery diseases, stroke, and thrombosis, are leading causes of death [21]. CVDs highly associate with many GPCRs which are expressed in heart $[20,22,23]$, the underlying mechanisms responsible for CVD are poorly understood. In view of the fact that alterations in GPCR pathways are linked to the developments of various CVDs [20,22-26], it would appear drugs that target GPCR pathways might be helpful for the prevention and/or treatment of CVDs. Although drugs used in CVDs bind same receptor, the pharmacologic effects of them are dependent on ligands [4,27]. Here, we discuss a novel GPCR pathway, called biased agonism, and the importance of biased drug development in cardiovascular diseases.

\section{$\beta$-Arrestins as Novel Signaling Molecules in GPCR Pathways}

Classical paradigms portend G-protein signals act in a linear manner [28-30], to activate various downstream pathways that increase levels of second messengers, such as, cAMP, DAG, and IP3 (Figure 1). In response to agonist binding, G Protein-Coupled Receptors (GPCRs) undergo conformational changes, and combinations of structural changes and receptor phosphorylation causes the recruitment of $\beta$-arrestin, which leads to signal desensitization via endocytosis of receptor-protein complexs (Figure 1). Furthermore, sequestration of these receptors from the cell surface is an important component of receptor desensitization and down-regulation $[9,11,14]$.

Recently, many researchers have reported GPCRs activate cytosolic signaling substrates, such as, MAPKs, Tyrosine Kinase (TK), AKT, PI3 Kinase (PI3K), and NF-kB, via $\beta$-arrestins, that is, in non-classical G protein independent manner (Figure 2). $\beta$-Arrestins act as scaffolds that bind various signaling molecules, including MAPKs, AKT, PI3K in various cells $[9,17,31-33]$. The proliferation of such findings shows GPCRs have multiple signal networks, and thus, there is a need to evaluate current drugs targeting GPCRs using different experimental tools to elucidate the nature of these networks.

\section{Biased Agonism of GPCRs}

The classical GPCRs signaling pathway presumes that bindings of ligands elicit their effects through one mechanism [28-30]. According to this paradigm, although agonists differ in terms of efficacy, their

*Corresponding author: Chi Dae Kim, Department of Pharmacology, School of Medicine, Pusan National University, Yangsan, Gyeongnam 626-870, Republic of Korea, Tel: 82-51-510-8063; Fax: 82-51-510-8068; E-mail: chidkim@pusan.ac.kr

Received July 17, 2016; Accepted July 28, 2016; Published August 02, 2016

Citation: Kim YH, Oh SO, Kim CD (2016) Biased Agonism of G Protein-Coupled Receptors: A Potential Therapeutic Strategy of Cardiovascular Diseases. Cardiovasc Pharm Open Access 5: 192. doi:10.4172/2329-6607.1000192

Copyright: ( $2016 \mathrm{Kim} \mathrm{YH}$, et al. This is an open-access article distributed under the terms of the Creative Commons Attribution License, which permits unrestricted use, distribution, and reproduction in any medium, provided the original author and source are credited. 


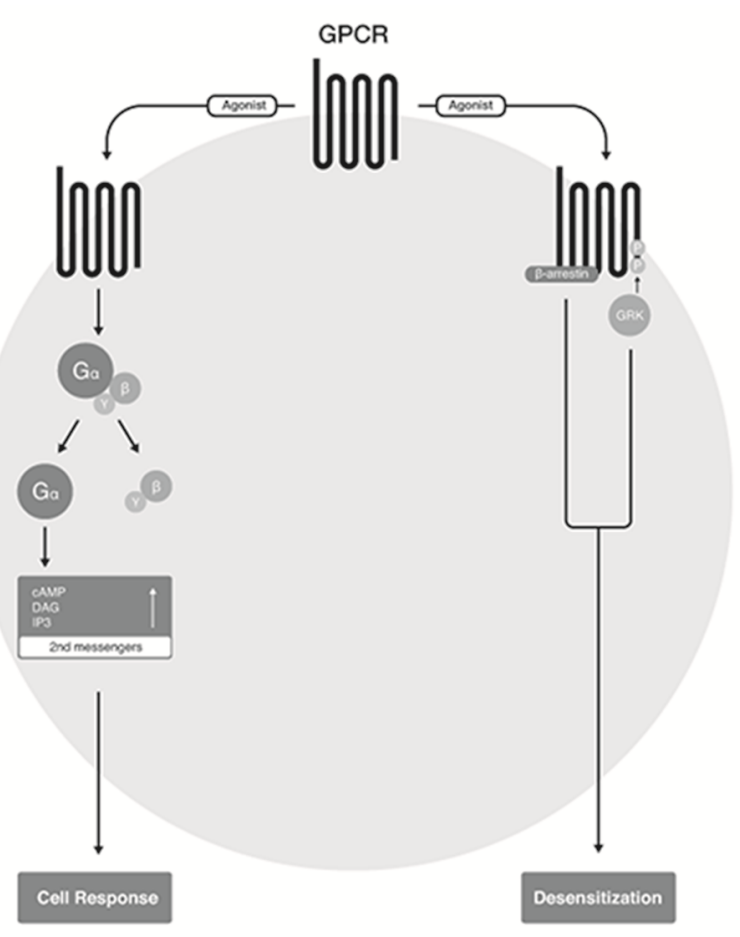

Figure 1: Classical paradigm of G Protein-Coupled Receptors (GPCRs) signaling pathway.

After agonist binding to GPCRs, activated receptor stimulates $G$ proteins and is phosphorylated by G Protein-Coupled Receptor Kinases (GRKs). The $\beta$-arrestin binds phosphorylated receptor and leads to desensitization.

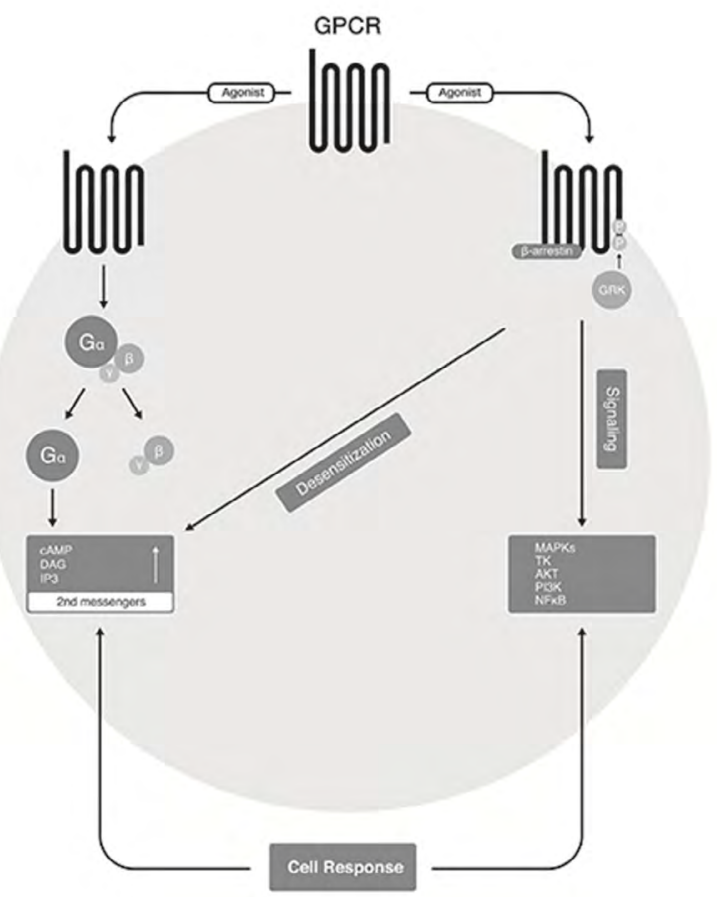

Figure 2: New paradigm of G Protein-Coupled Receptors (GPCRs) signaling pathway.

After agonist binding to GPCRs, the $\beta$-arrestin which was bound to receptor not only terminate G-protein signaling, but acts as scaffolds to activate several signaling molecules. elicited downstream effects are identical [34,35]. This concept is sufficient to determine the character of a ligand, i.e., full, partial, inverse agonist or neutral antagonist (Figure 3) [28,36,37]. However, agonists differ qualitatively (e.g., one agonist selectively activates one signal whereas another predominantly stimulates a different signal via the same receptor) and quantitatively (e.g. partial verses full) [28,36,37]. Thus, according to this expansion of the classical paradigm, agonists recognized by same GPCR elicits different types of responses.

Because ligands exhibit functional specificity via the same GPCR, the molecular pharmacologic concept of 'biased ligand' was proposed $[27,38,39]$. Interactions between GPCRs and $G$ proteins and $\beta$-arrestins represent general mechanisms of GPCR pharmacology and can initiate distinct signals, which are associated with specific physiological or pathophysiological consequences [20,22-26,40-42]. As shown in Figure 4 , ligands cause bias toward the $\mathrm{G}$ protein- or $\beta$-arrestin-mediated pathways, which suggests that biased ligands can be used to selectively to achieve greater beneficial or even negate unwanted results of GPCR activation, like side effects [43-45]. In past decades, several biased GPCR ligands have been identified that selectively target $G$ proteins or $\beta$-arrestins $[4,27]$. Thus, the characterization of GPCRs signaling pathways related to specific drugs is an essential prerequisite to the development of optimal therapeutic approaches.

The biased ligand concept proffers GPCRs adopt specific liganddependent conformations [10,46-49]. In particular, different ligand biases could stabilize distinct receptor conformations, and result in the transmissions of different signals to intracellular components $[46,47,50,51]$. Moreover, the bindings of different $\beta$-arrestin biased ligands to same GPCRs might activate other effectors in different ways $[18,52,53]$. About 400 GPCRs have pharmacologically relevant in human, only 30 GPCRs of structures have been reported [18]. It

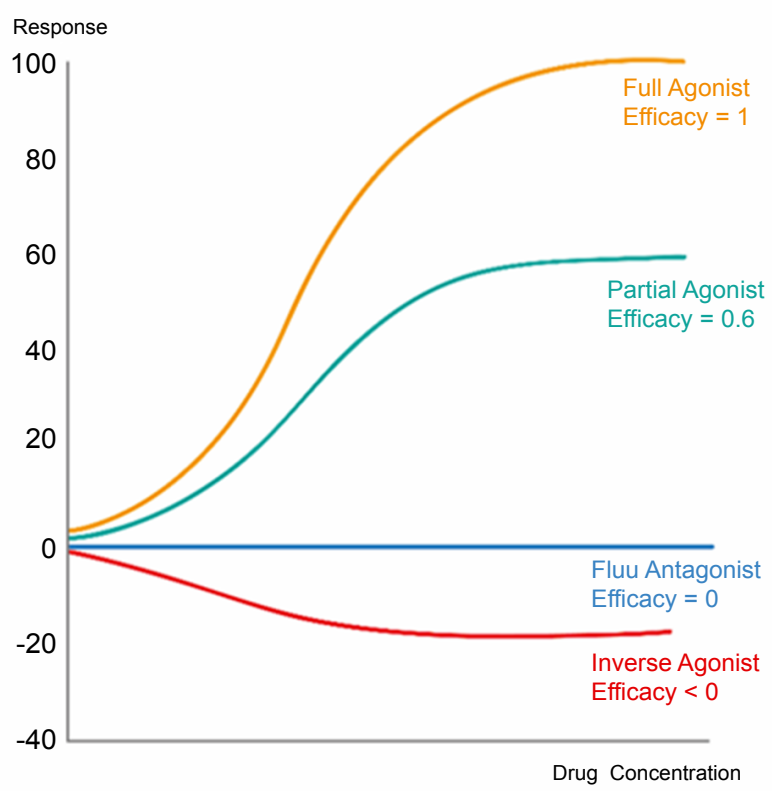

Figure 3: Interaction between ligand and receptor.

Full agonist: It binds to the certain receptor, and leads to produce full efficacy. Partial agonist: Although it binds to the same receptor, it produces only partial efficacy.

Full antagonist: It inhibits agonist-mediated pharmacological functions. Inverse agonist: It binds to the same receptor, however, it has opposite effect compared to agonist. 
is helpful to reveal 3-dimensioinal structures of GPCRs for designing biased ligands. Thus, understanding of structure-activity relationships is required for the developments effective therapeutics.

\section{Importance of Biased Ligands in the Background of CVD}

Numerous studies have been conducted on relations between GPCRs and disease states [19,20,22-26,42,54-59]. Angiotensin II (AngII) Type 1 Receptor (AT1R) and $\beta$-adrenergic receptors are probably the most important and well-studied GPCRs in the context of CVDs [60-65]. The Platelet-Activating Factor (PAFR) has an important role in the development of atherosclerosis (Figure 5 and Table 1) $[32,66,67]$.

\section{Angiotensin II (Ang II) Type 1 Receptor (AT R)}

As shown in Figure 6, AT1R, which is stimulated by Ang II, plays an important regulatory role in the cardiovascular system $[60,62,64,68$ 72]. Excessive stimulation by Ang II is detrimental and causes arterial hypertension, myocardial hypertrophy, and cardiac dysfunction [60,62,64,68-72]. Like other well-studied GPCRs, signaling of AT1R also occurs via $G$ proteins and $\beta$-arrestins pathways $[28,73]$, the characteristics of which have been investigated using mutant ligands that activate one pathway, signal inhibitors, siRNAs, and knockout mice $[60,62,64,65,68]$.

TRV120027, a $\beta$-arrestin biased ligand, reduces arterial pressure and increases cardiac contractility whereas $\mathrm{G}$ protein biased ligand, angiotensin II, causes vasoconstriction and fluid retention [72,74,75]. Insufficient cardiac output causes vasoconstriction by activating the Renin-Angiotensin System (RAS), which further impairs cardiac function because of the additional work required to maintain end organ perfusion [76,77]. It has been shown TRV120027 can block vasoconstriction induced by $\mathrm{G}$ protein activation and increase cardiac performance via $\beta$-arrestin biased signaling [72,74,75]. TRV120027 also suppresses angiotensin II-induced cardiac hypertrophy but enhances cardiac contractility [70]. Other $\beta$-arrestin biased ligand, TRV120026, has similar effects [4,64]. In this regard, $\beta$-arrestin biased ligands of AT1R offer a potentially efficient means of improving patient outcomes (Figure 6A).

\section{$\beta$-Adrenergic Receptors $(\beta$-AR)}

The adrenergic receptors are GPCR family members that target catecholamines, and the $\beta$-adrenergic receptors have been well studied [78-80]. Antagonists and agonists of adrenergic receptors are among the most clinically important drugs for the treatment of cardiovascular diseases $[81,82]$. In the cardiovascular system, $\beta 1$-adrenergic receptor ( $\beta 1-\mathrm{AR})$ specifically increases cardiac output by increasing heart rate, conduction velocity, and stroke volume [83-85], whereas $\beta 2$-AR controls vascular tone [86].

Recent research has revealed that carvedilol, a widely used $\beta$-blocker, activates ERK1/2 via $\beta$-arrestin in the absence of $G$ protein activation, and classical antagonists of $G$ protein signaling transactivate EGFR via a $\beta$-arrestin-dependent pathway [87-91]. These transactivations show that $\beta$-blocker, which acts as a $\beta$-arrestin biased ligand, has cardioprotective effects in-vitro and in-vivo systems [87-90]. However, it is thought that sustained $\beta 1-A R$ activation is cardiotoxic such as increasing apoptosis, heart rate, blood pressure via Gs signaling (Figure 6B) [92]. Moreover, carvedilol (a well-known $\beta$-blocker) acts as a $\beta$-arrestin-biased ligand for $\beta 1$-AR and $\beta 2$-AR $[88,91]$. Thus, the $\beta$-arrestin-dependent signaling of $\beta$-AR is expected to have a cardioprotective effect (Figure 6B).

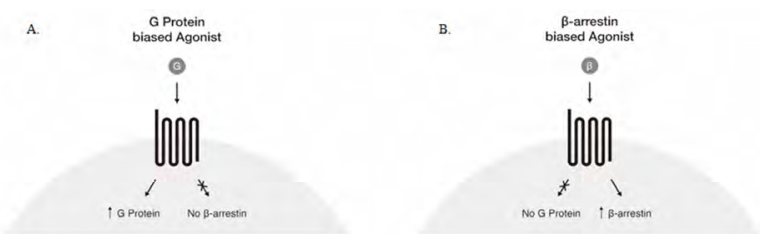

Figure 4: Schematic representation of biased ligands. (A) G protein biased ligand can only activate $G$ protein-related signals. (B) $\beta$-arrestin biased ligand do not activate $G$ protein-, but $\beta$-arrestin-mediated signaling pathways.

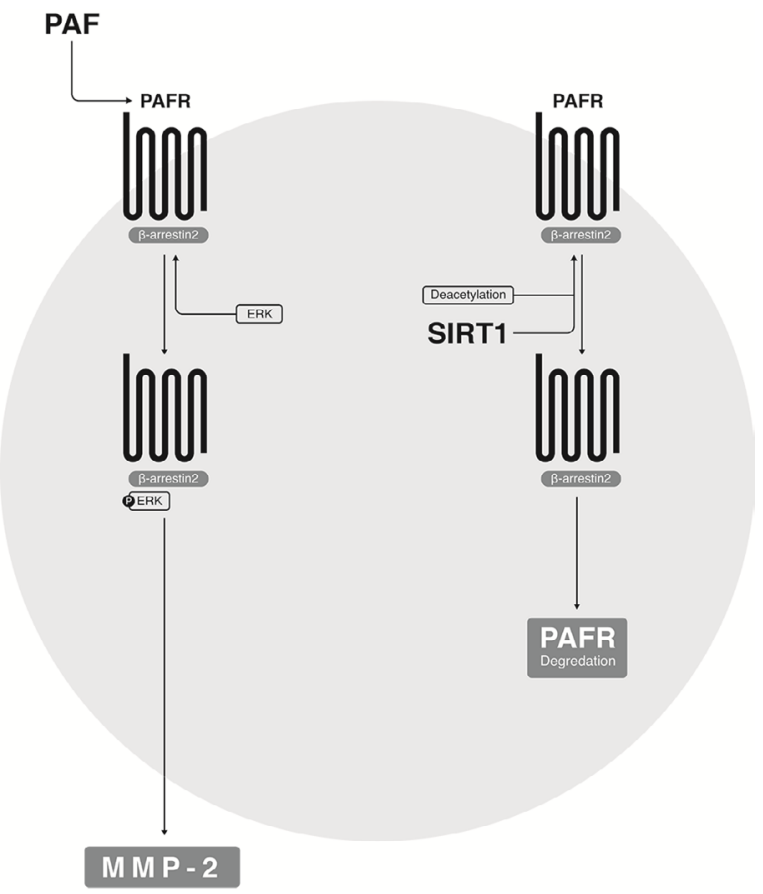

Figure 5: Protective role of SIRT1 in PAF-mediated $\beta$-arrestin signaling pathway.

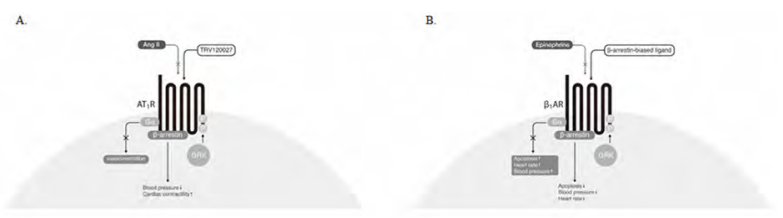

Figure 6: Examples of $\beta$-arrestin biased ligand of GPCRs. (A) TRV120027 do not activates $G$ proteins, but $\beta$-arrestin-mediated pathway after binding of AT1R. Angiotensin II (Angll) induces vasoconstriction via $G$ protein activation, however, TRV120027 has only beneficial effects via $\beta$-arrestin activation. (B) In $\beta 1 A R$ activation, $\beta$-arrestin-mediated signals have various good effects, but $\mathrm{G}$ protein activation induces high blood pressure, apoptosis and increasing heart rate.

\section{Platelet-Activating Factor Receptor (PAFR)}

Platelet Activating Factor (PAF), which binds to PAF receptor (a member of the GPCR family), was found to enhance matrixmetalloproteinase-2 (MMP-2) expression levels and MMP-2 is considered to make an important contribution to atherosclerotic plaque instability [32,66,93-95]. PAF-enhanced MMP-2 production has been shown to occur via activation of a $\beta$-arrestin-dependent ERK pathway (Figure 5) [32,66]. Interestingly, SIRT1 (silent mating type 
Citation: Kim YH, Oh SO, Kim CD (2016) Biased Agonism of G Protein-Coupled Receptors: A Potential Therapeutic Strategy of Cardiovascular Diseases. Cardiovasc Pharm Open Access 5: 192. doi:10.4172/2329-6607.1000192

Page 4 of 7

\begin{tabular}{|c|c|c|c|c|c|}
\hline GPCRs & Ligand & Bias & Function & $\begin{array}{c}\text { Dose for } \\
\text { biased action }\end{array}$ & References \\
\hline \multirow{3}{*}{$\begin{array}{l}\text { Angiotensin II Type I } \\
\text { Receptor }\left(\mathrm{AT}_{1} \mathrm{R}\right)\end{array}$} & Sar $^{1}$, Lys $^{5}$, Ala $^{8}$ Ang II (TRV120023) & $\beta$-arrestin-biased & Increased cardiac contractility & $\begin{array}{l}\sim 44 \mathrm{nM} \\
\left(\mathrm{EC}_{50}\right)\end{array}$ & {$[4,70]$} \\
\hline & $\begin{array}{l}\text { Sar }^{1}, \mathrm{Tyr}^{5}, \mathrm{Pro}^{7}-\mathrm{NH} 2 \mathrm{Ang} \text { II } \\
\text { (TRV120026) }\end{array}$ & $\beta$-arrestin-biased & $\begin{array}{c}\text { Reduced BP } \\
\text { Increased cardiac contractility }\end{array}$ & $\begin{array}{l}\sim 230 \mathrm{nM} \\
\left(\mathrm{EC}_{50}\right)\end{array}$ & {$[4,64]$} \\
\hline & Sar $^{1}, \mathrm{D}-\mathrm{Ala}^{8}$ Ang II (TRV120027) & $\beta$-arrestin-biased & $\begin{array}{c}\text { Reduced BP } \\
\text { Increased cardiac contractility }\end{array}$ & $\begin{array}{l}\sim 44 \mathrm{nM} \\
\left(\mathrm{EC}_{50}\right)\end{array}$ & {$[4,72]$} \\
\hline \multirow{2}{*}{$\beta_{1}$-adrenergic receptor } & Carvedilol & \multirow{2}{*}{$\beta$-arrestin-biased } & \multirow{2}{*}{$\begin{array}{l}\text { Cardioprotection (against catecholamine) } \\
\text { Increased cardiac contractility }\end{array}$} & $\begin{array}{l}\sim 2 \mathrm{nM} \\
\left(\mathrm{EC}_{50}\right)\end{array}$ & \multirow{2}{*}[84,88,89]{} \\
\hline & Alprenolol & & & $\begin{array}{l}\sim 59 \mathrm{nM} \\
\left(\mathrm{EC}_{50}\right)\end{array}$ & \\
\hline $\begin{array}{l}\text { Platelet Activating Factor } \\
\text { Receptor (PAFR) }\end{array}$ & Platelet activating factor & $\beta$-arrestin-biased & $\begin{array}{l}\text { Increased matrix metalloproteinase-2 } \\
\text { (MMP-2) }\end{array}$ & $\sim 1 \mathrm{nM}$ & [32] \\
\hline Apelin receptor & Stretch & $\beta$-arrestin-biased & Cardiac hypertropy & - & {$[26,99,100-105]$} \\
\hline $\begin{array}{l}\text { Sphingosine 1-phosphate } \\
\text { receptor-1 }\left(\mathrm{S}_{1} \mathrm{P}_{1}\right)\end{array}$ & 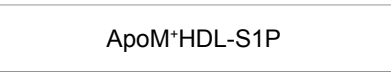 & $\beta$-arrestin-biased & Decreased vascular inflammation & $\sim 100 \mathrm{nM}$ & [109] \\
\hline
\end{tabular}

Table 1: Introduction of $\beta$-arrestin biased ligands of GPCRs related to cardiovascular diseases.

information regulation 2 homolog 1 ), is a key regulator of protection against vascular disorders and down-regulates PAFR via $\beta$-arrestinmediated internalization [66]. These results suggest deacetylation, a function of SIRT1, might be involved in GPCR regulation (Figure 5).

PAFR also plays a critical role in platelet aggregation $[96,97]$. Arachidonic acid, which is known to potent aggregation factor, induced platelet aggregation and thrombosis formation through PAFR [98]. SIRT1 down-regulates PAFR in platelets via proteasomal and/or lysosomal pathway [66]. SIRT1 activation suppresses platelet activation ex-vivo and pulmonary thromboembolism in-vivo [98]. Thus, elucidating $G$ protein-related signaling pathway of PAFR is important to develop new cardiovascular drugs targeting PAFR.

\section{Apelin receptor}

Apelin receptor, which is also one of the GPCR family, has similar sequence with the AT1 receptor [26,99]. However, the receptor does not respond to angiotensin II $[26,100]$. In Apelin receptor signaling pathway on vascular endothelial cells, biased toward G protein (MM07, Elabela/Toddler) signals has beneficial effects like vasodilation, increasing cardiac output [26,101-104]. MM07 or Elabela/Toddler showed $\beta$-arrestin biased actions at around $45 \mathrm{nM}$ or $100 \mathrm{nM}$. $\beta$-arrestin-related signaling by mechanical stretch in Apelin receptor causes cardiac hypertrophy whereas $G$ protein prevents the cardiac hypertrophy [26,105]. In case of Apelin receptor, $G$ protein signal is beneficial compared to $\beta$-arrestin pathway.

\section{Sphingosine-1-Phosphate 1 receptor (S1P1 receptor)}

Chronic inflammation induced by inflammatory macrophages plays critical role in the initiation and progression of cardiovascular diseases including atherosclerosis [106,107]. S1P enhances phenotypic changes of macrophages to anti-inflammatory phenotype [108]. In recent research, ApoM+HDL act as a $\beta$-arrestin biased ligand and it decreases vascular inflammation [109]. These results can support the cardiovascular protective role of HDL [109].

\section{Conclusion and Perspectives}

To make ideal drugs which offer safer, more efficacious for GPCRs, studies should focus on revealing the signals in detail and binding of ligand-receptor. Biased agonism is relatively novel concept, and despite the examples described above, comparatively few studies have been undertaken to elucidate the natures of GPCR pathway signals. Some research suggested functional bias is dependent on structures of ligands. Identification of receptor structures will support the structurebased drug design. These approaches will undoubtedly lead to the discovery of developing ideal biased ligands for therapeutics.

This review places emphasis on the $G$ protein $/ \beta$-arrestin bias concept because $G$ protein and $\beta$-arrestin are being directly targeted for drug discovery. We hope this article provides the motivation to better define the natures of GPCRs signals and aids the developments of more effective drugs on the basis of structures.

\section{Acknowledgment}

This work was supported by a 2-Year Research Grant of Pusan National University, Republic of Korea.

\section{References}

1. Lappano R, Maggiolini M (2011) G protein-coupled receptors: novel targets for drug discovery in cancer. Nat Rev Drug Discov 10: 47-60.

2. Pacher P, Batkai S, Kunos G (2006) The endocannabinoid system as an emerging target of pharmacotherapy. Pharmacol Rev 58: 389-462.

3. Chalmers DT, Behan DP (2002) The use of constitutively active GPCRs in drug discovery and functional genomics. Nat Rev Drug Discov 1: 599-608.

4. Whalen EJ, Rajagopal S, Lefkowitz RJ (2011) Therapeutic potential of $\beta$-arrestin- and G protein-biased agonists. Trends Mol Med 17: 126-139.

5. Lagerstram MC, Schiath HB (2008) Structural diversity of G protein-coupled receptors and significance for drug discovery. Nat Rev Drug Discov 7: 339-357.

6. Dunworth WP, Caron KM (2009) G protein-coupled receptors as potential drug targets for lymphangiogenesis and lymphatic vascular diseases. Arterioscler Thromb Vasc Biol 29: 650-656.

7. Ma P, Zemmel R (2002) Value of novelty? Nat Rev Drug Discov 1: 571-572.

8. Khoury E, Clement S, Laporte SA (2014) Allosteric and biased G proteincoupled receptor signaling regulation: potentials for new therapeutics. Front Endocrinol 5: 68

9. Lefkowitz RJ, Shenoy SK (2005) Transduction of receptor signals by betaarrestins. Science 308: 512-517.

10. Shukla AK, Singh G, Ghosh E (2014) Emerging structural insights into biased GPCR signaling. Trends Biochem Sci 39: 594-602.

11. Claing A (2002) Endocytosis of $G$ protein-coupled receptors: roles of $G$ proteincoupled receptor kinases and beta-arrestin proteins. Prog Neurobiol 66: 61-79.

12. Kohout TA, Lefkowitz RJ (2003) Regulation of G protein-coupled receptor kinases and arrestins during receptor desensitization. Mol Pharmacol 63: 9-18.

13. Lefkowitz RJ (2004) Historical review: a brief history and personal retrospective of seven-transmembrane receptors. Trends Pharmacol Sci 25: 413-422.

14. Shenoy SK,Lefkowitz RJ (2003) Multifaceted roles of beta-arrestins in the regulation of seven-membrane-spanning receptor trafficking and signalling. Biochem J 375: 503-515. 
Citation: Kim YH, Oh SO, Kim CD (2016) Biased Agonism of G Protein-Coupled Receptors: A Potential Therapeutic Strategy of Cardiovascular Diseases. Cardiovasc Pharm Open Access 5: 192. doi:10.4172/2329-6607.1000192

Page 5 of 7

15. Kobilka BK (2007) G protein coupled receptor structure and activation. Biochim Biophys Acta 1768: 794-807.

16. Kooistra AJ (2013) A structural chemogenomics analysis of aminergic GPCRs: lessons for histamine receptor ligand design. Br J Pharmacol 170: 101-26.

17. Pierce KL, Premont RT, Lefkowitz RJ (2002) Seven-transmembrane receptors. Nat Rev Mol Cell Biol 3: 639-650.

18. Brogi S, Tafi A, Desaubry L, Nebigil CG (2014) Discovery of GPCR ligands for probing signal transduction pathways. Front Pharmacol 5: 255.

19. Packiriswamy N, Parameswaran N (2015) G-protein-coupled receptor kinases in inflammation and disease. Genes Immun 16: 367-377.

20. Belmonte SL, Blaxall BC (2011) G protein coupled receptor kinases as therapeutic targets in cardiovascular disease. Circ Res 109: 309-319.

21. Pagidipati NJ, Gaziano TA (2013) Estimating deaths from cardiovascular disease: a review of global methodologies of mortality measurement. Circulation 127: 749-756

22. Salazar NC, Chen J, Rockman HA (2007) Cardiac GPCRs: GPCR signaling in healthy and failing hearts. Biochim Biophys Acta 1768: 1006-1018.

23. Seifert R, Wenzel-Seifert K (2002) Constitutive activity of G-protein-coupled receptors: cause of disease and common property of wild-type receptors. Naunyn Schmiedebergs Arch Pharmacol 366: 381-416.

24. Cannavo A, Liccardo D, Eguchi A, Elliott KJ, Traynham CJ, et al. (2016) Myocardial pathology induced by aldosterone is dependent on non-canonical activities of $G$ protein-coupled receptor kinases. Nat Commun 7: 10877.

25. Eclov JA, Qian Q, Redetzke R, Chen Q, Wu SC, et al. (2015) EPA, not DHA, prevents fibrosis in pressure overload-induced heart failure: potential role of free fatty acid receptor 4. J Lipid Res 56: 2297-2308.

26. Yang P, Maguire J, Davenport AP (2015) Apelin, Elabela/Toddler, biased agonists as novel therapeutic agents in the cardiovascular system. Trends Pharmacol Sci 36: 560-7.

27. Violin JD, Lefkowitz RJ (2007) Beta-arrestin-biased ligands at seventransmembrane receptors. Trends Pharmacol Sci 28: 416-422.

28. DeWire SM, Violin JD (2011) Biased ligands for better cardiovascular drugs: dissecting G-protein-coupled receptor pharmacology. Circ Res 109: 205-216.

29. Kenakin T (2005) New concepts in drug discovery: collateral efficacy and permissive antagonism. Nat Rev Drug Discov 4: 919-927.

30. Zhang W, Liu HT (2002) MAPK signal pathways in the regulation of cell proliferation in mammalian cells. Cell Res 12: 9-18.

31. DeFea KA (2000) The proliferative and antiapoptotic effects of substance $P$ are facilitated by formation of a beta -arrestin-dependent scaffolding complex. Proc Natl Acad Sci 97: 11086-11091.

32. Kim YH, Lee SJ, Seo KW, Bae JU, Park SY, et al. (2013) PAF enhances MMP2 production in rat aortic VSMCs via a ?-arrestin2-dependent ERK signaling pathway. J Lipid Res 54: 2678-2686

33. Luttrell LM, Ferguson SS, Daaka Y, Miller WE, Maudsley S, et al. (1999) Betaarrestin-dependent formation of beta2 adrenergic receptor-Src protein kinase complexes. Science 283: 655-661.

34. Kholodenko BN (2006) Cell-signalling dynamics in time and space. Nat Rev Mol Cell Biol 7: 165-176.

35. Zhang L, Loh HH, Law PY (2013) A novel noncanonical signaling pathway for the $\mu$-opioid receptor. Mol Pharmacol 84: 844-853.

36. Katritch V, Cherezov V, Stevens RC (2013) Structure-function of the G proteincoupled receptor superfamily. Annu Rev Pharmacol Toxicol 53: 531-556.

37. Zheng H, Loh HH, Law PY (2010) Agonist-selective signaling of G proteincoupled receptor: mechanisms and implications. IUBMB Life 62: 112-119.

38. Ingram SL, Traynor JR (2009) Role of protein kinase C in functional selectivity for desensitization at the mu-opioid receptor: from pharmacological curiosity to therapeutic potential. Br J Pharmacol 158: 154-156.

39. Russo A, Soh UJ, Trejo J (2009) Proteases display biased agonism at proteaseactivated receptors: location matters! Mol Interv 9: 87-96.

40. Luttrell LM, Gesty-Palmer D (2010) Beyond desensitization: physiological relevance of arrestin-dependent signaling. Pharmacol Rev 62: 305-30.
41. Schmid CL, Bohn LM (2009) Physiological and pharmacological implications of beta-arrestin regulation. Pharmacol Ther 121: 285-293.

42. Woodall MC, (2014) G protein-coupled receptor kinase 2: a link between myocardial contractile function and cardiac metabolism. Circ Res 114: 1661-1670.

43. Kenakin T, Christopoulos A (2013) Signalling bias in new drug discovery: detection, quantification and therapeutic impact. Nat Rev Drug Discov 12: 205-216.

44. Marti-Solano M, Guixa-Gonzalez R, Sanz F, Pastor M, Selent J (2013) Nove insights into biased agonism at $\mathrm{G}$ protein-coupled receptors and their potential for drug design. Curr Pharm Des 19: 5156-5166.

45. Valant C, May LT, Aurelio L, Chuo CH, White PJ, et al. (2014) Separation of on-target efficacy from adverse effects through rational design of a bitopic adenosine receptor agonist. Proc Natl Acad Sci 111: 4614-4619.

46. Deupi X, Li XD, Schertler GF (2012) Ligands stabilize specific GPCR conformations: but how? Structure 20: 1289-1290.

47. Okazaki M, Ferrandon S, Vilardaga JP, Bouxsein ML, Potts JT, et al. (2008) Prolonged signaling at the parathyroid hormone receptor by peptide ligands targeted to a specific receptor conformation. Proc Natl Acad Sci 105: 1652516530.

48. Roth S, Bruggeman FJ (2014) A conformation-equilibrium model captures ligand-ligand interactions and ligand-biased signalling by G-protein coupled receptors. FEBS J 281: 4659-4671.

49. Schultes S, Engelhardt H, Roumen L, Zuiderveld OP, Haaksma EE, et al. (2013) Combining quantum mechanical ligand conformation analysis and protein modeling to elucidate GPCR-ligand binding modes. ChemMedChem 8: 49-53.

50. Bhattacharya S, Hall SE, Li H, Vaidehi N (2008) Ligand-stabilized conformationa states of human beta(2) adrenergic receptor: insight into G-protein-coupled receptor activation. Biophys J 94: 2027-2042.

51. Venkatakrishnan AJ, Deupi X, Lebon G, Tate CG, Schertler GF, et al. (2013) Molecular signatures of G-protein-coupled receptors. Nature 494: 185-194.

52. Rominger DH, Cowan CL, Gowen-MacDonald W, Violin JD (2014) Biased ligands: pathway validation for novel GPCR therapeutics. Curr Opin Pharmacol 16: 108-115.

53. Santos GA, Duarte DA, Parreiras-e-Silva LT, Teixeira FR, Silva-Rocha R, et al. (2015) Comparative analyses of downstream signal transduction targets modulated after activation of the AT1 receptor by two beta-arrestin-biased agonists. Front Pharmacol 6: 131

54. Insel PA, Tang CM, Hahntow I, Michel MC (2007) Impact of GPCRs in clinical medicine: monogenic diseases, genetic variants and drug targets. Biochim Biophys Acta 1768: 994-1005.

55. Lania AG, Mantovani G, Spada A (2006) Mechanisms of disease: Mutations of $\mathrm{G}$ proteins and $\mathrm{G}$-protein-coupled receptors in endocrine diseases. Nat Clin Pract Endocrinol Metab 2: 681-693.

56. Sato PY, Chuprun JK, Schwartz M, Koch WJ (2015) The evolving impact of protein-coupled receptor kinases in cardiac health and disease. Physiol Rev 95: $377-404$

57. Schöneberg T, Schulz A, Biebermann H, Hermsdorf T, Römpler H, et al. (2004) Mutant G-protein-coupled receptors as a cause of human diseases. Pharmacol Ther 104: 173-206.

58. Trudel M, Yao Q, Qian F (2016) The Role of G-Protein-Coupled Receptor Proteolysis Site Cleavage of Polycystin-1 in Renal Physiology and Polycystic Kidney Disease. Cells 5: 3 .

59. Vassart G, Costagliola S (2011) G protein-coupled receptors: mutations and endocrine diseases. Nat Rev Endocrinol 7: 362-372.

60. Aplin M, Christensen GL, Schneider M, Heydorn A, Gammeltoft S, et al. (2007) Differential extracellular signal-regulated kinases 1 and 2 activation by the angiotensin type 1 receptor supports distinct phenotypes of cardiac myocytes. Basic Clin Pharmacol Toxicol 100: 296-301.

61. Conner DA, Mathier MA, Mortensen RM, Christe M, Vatner SF, et al. (1997) $\beta$-Arrestin1 knockout mice appear normal but demonstrate altered cardiac responses to beta-adrenergic stimulation. Circ Res 81: 1021-1026.

62. Daniels D, Yee DK, Faulconbridge LF, Fluharty SJ (2005) Divergent behavioral roles of angiotensin receptor intracellular signaling cascades. Endocrinology 146: $5552-5560$ 
Citation: Kim YH, Oh SO, Kim CD (2016) Biased Agonism of G Protein-Coupled Receptors: A Potential Therapeutic Strategy of Cardiovascular Diseases. Cardiovasc Pharm Open Access 5: 192. doi:10.4172/2329-6607.1000192

Page 6 of 7

63. Morris GE, Nelson CP, Everitt D, Brighton PJ, Standen NB, et al. (2011) G protein-coupled receptor kinase 2 and arrestin2 regulate arterial smooth muscle P2Y-purinoceptor signalling. Cardiovasc Res 89: 193-203.

64. Rajagopal K, Whalen EJ, Violin JD, Stiber JA, Rosenberg PB, et al. (2006) Beta-arrestin2-mediated inotropic effects of the angiotensin II type $1 \mathrm{~A}$ receptor in isolated cardiac myocytes. Proc Natl Acad Sci USA 103: 16284-16289.

65. Zhai P, Yamamoto M, Galeotti J, Liu J, Masurekar M, et al. (2005) Cardiacspecific overexpression of AT1 receptor mutant lacking $G$ alpha q/G alpha coupling causes hypertrophy and bradycardia in transgenic mice. J Clin Invest 115: 3045-3056.

66. Kim YH, Bae JU, Lee SJ, Park SY, Kim CD (2015) SIRT1 attenuates PAFinduced MMP-2 production via down-regulation of PAF receptor expression in vascular smooth muscle cells. Vascul Pharmacol 72: 35-42.

67. Montrucchio G, Alloatti G, Camussi G (2000) Role of platelet-activating factor in cardiovascular pathophysiology. Physiol Rev 80: 1669-1699.

68. Ahn S, Shenoy SK, Wei H, Lefkowitz RJ (2004) Differential kinetic and spatial patterns of beta-arrestin and $G$ protein-mediated ERK activation by the angiotensin II receptor. J Biol Chem 279: 35518-35525.

69. Benigni A, Corna D, Zoja C, Sonzogni A, Latini R, et al. (2009) Disruption of the Ang II type 1 receptor promotes longevity in mice. J Clin Invest 119: 524-530.

70. Monasky MM, Taglieri DM, Henze M, Warren CM, Utter MS, et al. (2013) The beta-arrestin-biased ligand TRV120023 inhibits angiotensin II-induced cardiac hypertrophy while preserving enhanced myofilament response to calcium. Am J Physiol Heart Circ Physiol 305: H856-H866.

71. Sechi LA, Griffin CA, Grady EF, Kalinyak JE, Schambelan M (1992) Characterization of angiotensin II receptor subtypes in rat heart. Circ Res 71: 1482-1489.

72. Violin JD, DeWire SM, Yamashita D, Rominger DH, Nguyen L, et al. (2010) Selectively engaging $\hat{I}^{2}$-arrestins at the angiotensin II type 1 receptor reduces blood pressure and increases cardiac performance. J Pharmacol Exp Ther 335: 572-579.

73. Lohse MJ, Andexinger S, Pitcher J, Trukawinski S, Codina J, et al. (1992) Receptor-specific desensitization with purified proteins. Kinase dependence and receptor specificity of beta-arrestin and arrestin in the beta 2-adrenergic receptor and rhodopsin systems. J Biol Chem 267: 8558-8564.

74. Boerrigter G, Michael WL, Erin JW, David GS, Jonathan DV, et al. (2011) Cardiorenal actions of TRV120027, a novel $\beta$-arrestin-biased ligand at the angiotensin II type I receptor, in healthy and heart failure canines: a nove therapeutic strategy for acute heart failure. Circ Heart Fail 4: 770-778.

75. Boerrigter G, Soergel DG, Violin JD, Lark MW, Burnett JC (2012) TRV120027, a novel beta-arrestin biased ligand at the angiotensin II type I receptor, unloads the heart and maintains renal function when added to furosemide in experimental heart failure. Circ Heart Fail 5: 627-634.

76. Pacurari M, Kafoury R, Tchounwou PB, Ndebele K (2014) The ReninAngiotensin-aldosterone system in vascular inflammation and remodeling. Int $\mathrm{J}$ Inflam 2014.

77. Paul M, Poyan Mehr A, Kreutz R (2006) Physiology of local renin-angiotensin systems. Physiol Rev 86: 747-803.

78. Johnson M (2006) Molecular mechanisms of beta(2)-adrenergic receptor function, response, and regulation. J Allergy Clin Immunol 117: 18-24.

79. Post SR, Hammond HK, Insel PA (1999) $\beta$-adrenergic receptors and receptor signaling in heart failure. Annu Rev Pharmacol Toxicol 39: 343-360.

80. Wachter SB, Gilbert EM (2012) Beta-adrenergic receptors, from their discovery and characterization through their manipulation to beneficial clinical application. Cardiology 122: 104-112.

81. Frishman WH (2008) beta-Adrenergic blockers: a 50-year historical perspective. Am J Ther 15: 565-576.

82. Yoo B, Lemaire A, Mangmool S, Wolf MJ, Curcio A, et al. (2009) Beta1adrenergic receptors stimulate cardiac contractility and CaMKII activation in vivo and enhance cardiac dysfunction following myocardial infarction. Am J Physiol Heart Circ Physiol 297: 1377-1386.

83. Bristow MR (2000) beta-adrenergic receptor blockade in chronic heart failure. Circulation 101: 558-569.

84. Rohrer DK, Desai KH, Jasper JR, Stevens ME, Regula DP Jr, et al. (1996) Targeted disruption of the mouse beta1-adrenergic receptor gene: developmental and cardiovascular effects. Proc Natl Acad Sci 93: 7375-7380.

85. Wisbach G, Gordon MC, Steven VC, Ryan BS, Aaron MD, et al. (2007) Preserving cardiac output with beta-adrenergic receptor blockade and inhibiting the Bezold-Jarisch reflex during resuscitation from hemorrhage. J Trauma 63 : 26-32.

86. Pourageaud F, Leblais V, Bellance N, Marthan R, Muller B (2005) Role of beta2-adrenoceptors (beta-AR), but not beta1-, beta3-AR and endothelial nitric oxide, in beta-AR-mediated relaxation of rat intrapulmonary artery. Naunyn Schmiedebergs Arch Pharmacol 372: 14-23.

87. Belmonte SL, Blaxall BC (2012) Conducting the G-protein Coupled Receptor (GPCR) Signaling Symphony in Cardiovascular Diseases: New Therapeutic Approaches. Drug Discov Today Dis Models 9: 85-90.

88. Kim IM, Tilley DG, Chen J, Salazar NC, Whalen EJ, et al. (2008) Betablockers alprenolol and carvedilol stimulate beta-arrestin-mediated EGFR transactivation. Proc Natl Acad Sci 105: 14555-14560.

89. Noma T, Lemaire A, Naga Prasad SV, Barki-Harrington L, Tilley DG, et al (2007) Beta-arrestin-mediated beta1-adrenergic receptor transactivation of the EGFR confers cardioprotection. J Clin Invest 117: 2445-2458.

90. Patel CB, Noor N, Rockman HA (2010) Functional selectivity in adrenergic and angiotensin signaling systems. Mol Pharmacol 78: 983-992.

91. Wisler JW, DeWire SM, Whalen EJ, Violin JD, Drake MT, et al. (2007) A unique mechanism of beta-blocker action: carvedilol stimulates beta-arrestin signaling Proc Natl Acad Sci 104: 16657-16662.

92. Lohse MJ, Engelhardt S, Eschenhagen T (2003) What is the role of betaadrenergic signaling in heart failure? Circ Res 93: 896-906.

93. Caird J, Napoli C, Taggart C, Farrell M, Bouchier-Hayes D (2006) Matrix metalloproteinases 2 and 9 in human atherosclerotic and non-atherosclerotic cerebral aneurysms. Eur J Neurol 13: 1098-1105.

94. Kuzuya M, Nakamura K, Sasaki T, Cheng XW, Itohara S, et al. (2006) Arterioscler Thromb Vasc Biol 26: 1120-1125.

95. Wågsäter D, Zhu C, Björkegren J, Skogsberg J, Eriksson P (2011) MMP-2 and MMP-9 are prominent matrix metalloproteinases during atherosclerosis development in the Ldlr(-/-)Apob(100/100) mouse. Int J Mol Med 28: 247-253.

96. Demopoulos CA, Pinckard RN, Hanahan DJ (1979) Platelet-activating factor Evidence for 1-O-alkyl-2-acetyl-sn-glyceryl-3-phosphorylcholine as the active component. J Biol Chem 254: 9355-9358.

97. Koch E (2005) Inhibition of platelet activating factor (PAF)-induced aggregation of human thrombocytes by ginkgolides: considerations on possible bleeding complications after oral intake of Ginkgo biloba extracts. Phytomedicine 12: 10-6.

98. Kim YH, Bae JU, Kim IS, Chang CL, Oh SO, et al. (2016) SIRT1 prevents pulmonary thrombus formation induced by arachidonic acid via downregulation of PAF receptor expression in platelets. Platelets 8: 1-8.

99. O'Dowd BF, Heiber M, Chan A, Heng HH, Tsui LC, et al. (1993) A human gene that shows identity with the gene encoding the angiotensin receptor is located on chromosome 11. Gene 136: 355-360.

100. Tatemoto K, Hosoya M, Habata Y, Fujii R, Kakegawa T, et al. (1998) Isolation and characterization of a novel endogenous peptide ligand for the human APJ receptor. Biochem Biophys Res Commun 251: 471-476.

101. Murza A (2016) Discovery and Structure-Activity Relationship of a Bioactive Fragment of ELABELA that Modulates Vascular and Cardiac Functions. $J$ Med Chem 59: 2962-72.

102. Iturrioz X, Gerbier R, Leroux V, Alvear-Perez R, Maigret B, et al. (2010) By interacting with the C-terminal Phe of apelin, Phe255 and Trp259 in helix VI of the apelin receptor are critical for internalization. J Biol Chem 285: 32627 32637.

103. Iturrioz X, Alvear-Perez R, De Mota N, Franchet C, Guillier F, et al. (2010) Identification and pharmacological properties of E339-3D6, the first nonpeptidic apelin receptor agonist. FASEB J 24: 1506-1517.

104. Brame AL, Maguire JJ, Yang P, Dyson A, Torella R, et al. (2015) Design, characterization, and first-in-human study of the vascular actions of a novel biased apelin receptor agonist. Hypertension 65: 834-840.

105. Dai T, Ramirez-Correa G, Gao WD (2006) Apelin increases contractility in failing cardiac muscle. Eur J Pharmacol 553: 222-228. 
Citation: Kim YH, Oh SO, Kim CD (2016) Biased Agonism of G Protein-Coupled Receptors: A Potential Therapeutic Strategy of Cardiovascular Diseases. Cardiovasc Pharm Open Access 5: 192. doi:10.4172/2329-6607.1000192

Page 7 of 7

106. Pearson TA, Mensah GA, Alexander RW, Anderson JL, Cannonal RO (2003) Markers of inflammation and cardiovascular disease: application to clinical and public health practice: A statement for healthcare professionals from the Centers for Disease Control and Prevention and the American Heart Association. Circulation 107: 499-511.

107. Willerson JT, Ridker PM (2004) Inflammation as a cardiovascular risk factor. Circulation 109: 102-110.
108. Hughes JE, Srinivasan S, Lynch KR, Proia RL, Ferdek P, et al. (2008) Sphingosine-1-phosphate induces an antiinflammatory phenotype in macrophages. Circ Res 102: 950-958.

109. Galvani S, Sanson M, Blaho VA, Swendeman SL, Obinata H, et al. (2015) HDL-bound sphingosine 1-phosphate acts as a biased agonist for the endothelial cell receptor S1P1 to limit vascular inflammation. Sci Signal 8: ra79. 